\title{
Proposition of a General Scoring System to the BackPEI
}

\author{
Luiza Rampi Pivotto, Bruna Nichele da Rosa, Cláudia Tarragô Candotti*, Matias Noll, Adriane Vieira and \\ Jefferson Fagundes Loss
}

Exercise Research Laboratory \& School of Physical Education, Physical Therapy and Dance of Federal University of Rio Grande do Sul, Brazil

Submission: September 26, 2018; Published: October 03, 2018

*Corresponding author: Cláudia Tarragô Candotti, Exercise Research Laboratory \& School of Physical Education, Physical Therapy and Dance of Federal University of Rio Grande do Sul, Rua Felizardo, no 750 - Jardim Botânico-Porto Alegre, Rio Grande do Sul, Brasil, Tel: 5133085861; Email: claudia.candotti@ufrgs.br

\section{Abstract}

Questionnaires are important tools to assessment due its easy application, low charge and possibility of self-report of the assessed. The Back Pain and Body Posture Evaluation Instrument (BackPEI) and the Back Pain and Body Posture Evaluation Instrument for Adults (BackPEI-A) are questionnaires to assess the back-pain presence and associated risk factors. The BackPEI assess only school children while BackPEI-A assess only adults and has a score system which indicates the subject risk factors exposition level to back pain development. The aim is proposing a score system specific to BackPEI. The score system uses only those questions involving risk factors to back pain development, such as: physical exercise practice; time spent watching television and using computer; number of hours sleeping and habit of reading/studying on bed; occurrence of back pain among parents; postures adopted to sleep, to sit, to write, to use computer and to lift an object from the ground; school bag used to transport material and mode of transportation school bag; and parents' schooling. As higher as the score, lower is the risk factors exposition to back pain. From this communication, BackPEI has a general score system which expresses the level of risk factor exposition to back pain development among school children.

Keywords: Back pain; Posture; Adolescent; Development; Questionnaire

Abbreviations: BackPEI: Back Pain and Body Posture Evaluation Instrument; BackPEI-A: Back Pain and Body Posture Evaluation Instrument for Adults

\section{Introduction}

It's been increasing the interesting to investigate the risk factors related to spine. This is due to high prevalence of postural changes and of back pain. These problems affect not only the adults [1-5], but also children and adolescents [6-10]. Most epidemiologic studies which investigate back pain and associated risk factors use questionnaires, due the easy application, low charge and possibility of self-report of assessed [11-15].

The BackPEI and BackPEI-A are questionnaires developed to assess both back pain presence and the associated risk factors, presenting validity and reliability proven. The BackPEI have 21 multiple choice questions [16] which assess only school children (from 11 to 16 years old). The BackPEI-A assesses exclusively adults and is composed by 20 multiple choice. Only the BackPEI-A presents a score system indicating the exposition level of risk factors to back pain development [17]. In this perspective, the aim of this short communication is proposing a score system specific to BackPEI.

\section{Methods}

The general score system proposed to BackPEI involves only the questions related to risk factors to back pain development among children and adolescents, such as: physical exercise practice (questions 1 and 3) [11,18]; time spent watching television (question 4) and using computer (question 5); number of hours sleeping (question 8) and habit of reading/studying on bed (question 6) $[10,19,20]$; occurrence of back pain among parents (question 17) [20,21]; posture adopted to sleep (question 7); to sit on a chair (question 10), to write (question 9), to use computer (question 11) and to lift an object from the ground (question 12) [22,23]; school bag used to transport material and mode of transportation school bag (questions 13 and 14) [24,25]; and parents' schooling (questions 15 and 16) [21].

On question 1, affirmative answer scores 1 , while negative answer scores 0 . The question 2 does not score. On questions 3, 6 and 17 , affirmative answer scores 0 and negative answer scores 1 . On questions 4 and 5, the options containing up to 3 hours per day score 1 and the options from 4 hours per day score 0 . On question 7 , the option "face down (on my stomach)" scores 0 , while the other options score 1 . On question 8 , options containing less than 7 hours spent sleeping per night score 0 and the other options score 1 . On questions $9-12$ and 14, the suitable postures score 1 , and the unsuitable postures score 0 . On these questions, only 
one option is considered suitable. On question 13, the options containing backpack with 2 straps, backpack with 1 strap and wheeled backpack score 1 , while the others options score 0 . On questions 15 and 16, the options "higher education (University)" and "secondary school (1st to 3rd grade)" score 1, and the other options score 0 . The final score is resulting from sum of all scores (maximum of 16 points). As higher as the score, lower is the risk factor exposition to back pain development.

\section{Conclusion}

From this short communication, the BackPEI questionnaire now has available a general score system, like the BackPEI-A has. This score aims to express how much the school children assessed is exposed to risk factors related to back pain development.

\section{References}

1. Alperovitch-Najenson D, Santo Y, Masharawi Y, Katz-Leurer M, Ushvaev D, et al. (2010) Low back pain among professional bus drivers: ergonomic and occupational-psychosocial risk factors. Isr Med Assoc J 12(1): 26-31.

2. Ferreira GD, Silva MC, Rombaldi AJ, Wrege ED, Siqueira FV, et al. (2011) Prevalence and associated factors of back pain in adults from southern brazil: A population-based study | Prevalência de dor nas costas e fatores associados em adultos do Sul do Brasil: estudo de base populacional. Rev Bras Fisioter 15(1).

3. Candotti CT, Noll M, Cruz M (2010) Prevalência De Dor Lombar E Os Desequilíbrios Musculares Em Manicures. Rev Eletrônica da Esc Educ Física e Desportos UFRJ. 6(1): 125-140.

4. Elders LAM, Burdorf A (2004) Prevalence, incidence, and recurrence of low back pain in scaffolders during a 3-year follow-up study. Spine (Phila Pa 1976) 29(6): E101-E106.

5. Candotti CT, Noll M, Marchetti BV, Rosa BN da, Medeiros M da GS, et al. (2015). Prevalence of back pain, functional disability, and spinal postural changes. Fisioter em Mov 28(4): 711-722.

6. Aartun E, Hartvigsen J, Wedderkopp N, Hestbaek L (2014) Spinal pain in adolescents: prevalence, incidence, and course: a school-based two-year prospective cohort study in 1,300 Danes aged 11-13. BMC Musculoskelet Disord 15(1): 187-194.

7. Muñoz IC, Conesa AG, Meca JS (2013) Prevalence of low back pain in children and adolescents: a meta-analysis. BMC Pediatr 13(1): 14.

8. Minghelli B, Oliveira R, Nunes C (2014) Non-specific low back pain in adolescents from the south of Portugal: prevalence and associated factors. J Orthop Sci 19(6): 883-892.

9. Noll M, Noll PR e S, Neto JLR, Leal VN, Rosa BN da, et al. (2017) Back pain and behavioral habits of high school students: a comparative study of two Brazil's regions. Rev Bras Reumatol Engl Ed 57(5): 495-499.

10. Paananen MV, Auvinen JP, Taimela SP, Tammelin TH, Kantomaa MT, et al. (2010). Psychosocial, mechanical, and metabolic factors in adolescents' musculoskeletal pain in multiple locations: A cross-sectional study. Eur J Pain 14(4): 395-401.
11. Balagué F, Troussier B, Salminen JJ (1999) Non-specific low back pain in children and adolescents: Risk factors. Eur Spine J 8(6): 429-438.

12. Schlademann S, Meyer T, Raspe H (2008) The test-retest reliability of a questionnaire on the occurrence and severity of back pain in a German population sample. Int J Public Health 53(2): 96-103.

13. Staes F, Stappaerts K, Vertommen H, Everaert D, Coppieters M (1999) Reproducibility of a survey questionnaire for the investigation of low back problems in adolescents. Acta Paediatr Int J Paediatr 88(11): 1269-1273.

14. Real MTGD, Kovacs FM, Gestoso M, Mufraggi N, Diéguez JM, et al. (1999) Evaluation of two questionnaires to determine exposure to risk factors for non-specific low back pain in Mallorcan schoolchildren and their parents. Eur J Public Health 9(3): 194-199.

15. Mehta TB, Thorpe DE, Freburger JK (2002) Development of a survey to assess backpack use and neck and back pain in seventh and eighth graders. Pediatr Phys Ther 14(4): 171-184.

16. Noll M, Tarragô Candotti C, Vieira A, Fagundes Loss J (2013) Back pain and body posture evaluation instrument (BackPEI): development, content validation and reproducibility. Int J Public Heal 58(4): 565-572.

17. Candotti CT, Schmit EFD, Pivotto LR, Raupp EG, Noll M, et al. (2018) Back Pain and Body Posture Evaluation Instrument for Adults: Expansion and Reproducibility. Pain Nurs Manag 19(4): 415-423.

18. Bo Andersen L, Wedderkopp N, Leboeuf-Yde C (2006) Association between back pain and physical fitness in adolescents. Spine (Phila Pa 1976) 31(15): 1740-1744.

19. Auvinen JP, Tammelin TH, Taimela SP, Zitting PJ, Järvelin MR, et al. (2010). Is insufficient quantity and quality of sleep a risk factor for neck, shoulder and low back pain? A longitudinal study among adolescents. Eur Spine J 19(4): 641-649.

20. O'Sullivan P, Smith A, Beales D, Straker L (2017). Understanding Adolescent Low Back Pain From a Multidimensional Perspective: Implications for Management. J Orthop Sport Phys Ther 47(10): 741751.

21. Masiero S, Carraro E, Celia A, Sarto D, Ermani M (2008) Prevalence of nonspecific low back pain in school children aged between 13 and 15 years. Acta Pediatr 97: 212-216.

22. Limon S, Valinsky LJ, Ben-Shalom Y (2004) Children at risk: risk factors for low back pain in the elementary school environment. Spine (Phila Pa 1976) 29(6): 697-702.

23. Salem K Ben, Bejia I, Abid N, Salem K Ben, Letaief M, et al. (2005). Low back pain in a cohort of 622 Tunisian schoolchildren and adolescents: an epidemiological study. Eur Spine J 14(4): 331-336.

24. Dochrell S, Kane C, O'keefe E (2006) Schoolbag weight and the effects of schoolbag carriage on secondary school students. Meeting Divers Ergon $9^{\text {th }}-14^{\text {th }}$.

25. Candotti CT, Noll M, Roth E (2012) Assessment of weight and mode of transport of school material in highschool students. Rev Paul Pediatr 30(1): 100-106. 
This work is licensed under Creative Commons Attribution 4.0 License DOI: 10.19080/JHNSS.2018.03.555618
Your next submission with Juniper Publishers will reach you the below assets

- Quality Editorial service

- Swift Peer Review

- Reprints availability

- E-prints Service

- Manuscript Podcast for convenient understanding

- Global attainment for your research

- Manuscript accessibility in different formats ( Pdf, E-pub, Full Text, Audio)

- Unceasing customer service

Track the below URL for one-step submission https://juniperpublishers.com/online-submission.php 